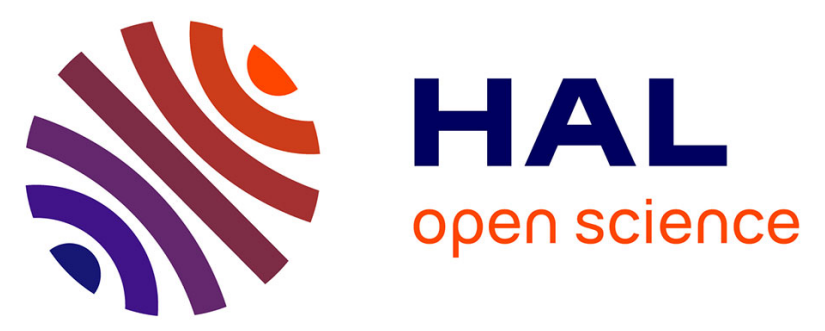

\title{
Meaningfully engaging the next generation of ecosystem services specialists
}

Diana M Hackenburg, Alison Adams, Katherine Brownson, Israel T Borokini, Tatiana M Gladkikh, Shannon C Herd-Hoare, Helina Jolly, Andrew N Kadykalo, Erika B Kraus, Kelsey R Mcdonough, et al.

\section{To cite this version:}

Diana M Hackenburg, Alison Adams, Katherine Brownson, Israel T Borokini, Tatiana M Gladkikh, et al. Meaningfully engaging the next generation of ecosystem services specialists. Ecosystem Services, 2019, 40, pp.101041. 10.1016/j.ecoser.2019.101041 . hal-02894380

\section{HAL Id: hal-02894380 \\ https://hal-enpc.archives-ouvertes.fr/hal-02894380}

Submitted on 8 Jul 2020

HAL is a multi-disciplinary open access archive for the deposit and dissemination of scientific research documents, whether they are published or not. The documents may come from teaching and research institutions in France or abroad, or from public or private research centers.
L'archive ouverte pluridisciplinaire HAL, est destinée au dépôt et à la diffusion de documents scientifiques de niveau recherche, publiés ou non, émanant des établissements d'enseignement et de recherche français ou étrangers, des laboratoires publics ou privés. 


\title{
Meaningfully engaging the next generation of ecosystem services specialists
}

\author{
Diana M. Hackenburg ab, Alison Adams ${ }^{\text {ab }}$, Katherine Brownson ${ }^{c}$, Israel T. Borokini ${ }^{\text {d, }}$ \\ Tatiana M. Gladkikh ${ }^{\text {ab }}$, Shannon C. Herd-Hoare ${ }^{\mathrm{e}}$, Helina Jolly ${ }^{\mathrm{f}}$, Andrew N. \\ Kadykalo $^{g}$, Erika B. Kraus ${ }^{\text {h }}$, Kelsey R. McDonough ${ }^{\text {i }}$, Joshua W. Morse ${ }^{\text {ab }}$, Saroop S. \\ Sandhu ${ }^{\mathrm{j}}$, Navchaa Tugjamba ${ }^{\mathrm{k}}$, Améline Vallet ${ }^{\mathrm{lm}}$
}

a Rubenstein School of Environment and Natural Resources, University of Vermont, Aiken Center, 81 Carrigan Drive, Burlington, VT 05405, United States

b Gund Institute for Environment, University of Vermont, 617 Main Street, Johnson House, Burlington, VT 05405, United States

c Odum School of Ecology, University of Georgia, 140 E. Green St., Athens, GA 30602, United States

d Program in Ecology, Evolution and Conservation Biology, Department of Biology, University of Nevada Reno, Reno, NV 89557, United States

e Department of Environmental Science, Rhodes University, Grahamstown, 6140, South Africa

f Institute for Resources Environment and Sustainability, University of British Columbia, AERL Building, 429-2202

Main Mall, Vancouver, BC, V6T 1Z4, Canada

g Department of Biology and Institute of Environmental and Interdisciplinary Sciences, Carleton University, 1125 Colonel By Drive, Ottawa, Ontario K1S 5B6, Canada

h Department of Forestry, Michigan State University, 480 Wilson Road, East Lansing, MI 48824, United States

i Professorship of Ecological Services, Faculty of Biology, Chemistry, and Earth Sciences, BayCEER, University of Bayreuth, Universitaetsstr. 30, 95440 Bayreuth, Germany

j Department of Agronomy, University of Florida, 1676 McCarty drive, Gainesville, FL 32611, United States

k Department of Geography and Planning, Building W3A, Macquarie University, NSW 2109, Australia

1 Ecologie Systématique Evolution, AgroParisTech, CNRS, Université Paris-Sud, Université Paris-Saclay, 362 Rue du Doyen André Guinier, 91405 Orsay, France

m CIRED, AgroParisTech, Cirad, CNRS, EHESS, Ecole des Ponts ParisTech, Université Paris-Saclay, 45 bis Avenue de la Belle Gabrielle, 94130 Nogent-sur-Marne, France

Manuscript published in Ecosystem Services: Hackenburg, D. M., Adams, A., Brownson, K., Borokini, I. T., Gladkikh, T. M., Herd-Hoare, S. C., .. Vallet, A. (2019). Meaningfully engaging the next generation of ecosystem services specialists. Ecosystem Services, 40, 101041.

doi:10.1016/j.ecoser.2019.101041

Received 27 August 2019, Revised 7 October 2019, Accepted 11 October 2019, Available online 30 October 2019. 


\section{Highlights}

- Fourteen early-career specialists (ECS) share their perspectives on engagement.

- Challenges in engaging people in ES could limit the influx of new talent.

- ECS possess perspectives and skills valuable to broadening the reach of ES.

- Recommendations provide actionable steps for increasing meaningful engagement.

\section{Abstract}

The Ecosystem Services community needs to think carefully about how to develop and engage the next generation of leaders. Entering the field presents both challenges and rewards for early-career specialists (ECS). In this commentary, we provide recommendations for meaningful engagement of ECS in an effort to grow and broaden the value of ecosystem services as a framework for sustainability.

\section{Keywords}

Early-career specialists; Ecosystem services; Professional development; Young ecosystem services specialists 


\section{Commentary}

As the field of ecosystem services (ES) continues to grow, novel opportunities abound to engage with diverse disciplines (Bennett, 2017; van Riper et al., 2017), social justice issues (Dawson et al., 2018; Schröter et al., 2017), and emerging paradigms, such as nature's contributions to people (Peterson et al., 2018), relational values (Himes and Muraca, 2018), and shared values (Irvine et al., 2016). Particularly, the ES field must usher in a new generation of scholars, practitioners, and policymakers who are beginning their careers. Harnessing the next generation of specialists' new perspectives, strengths, and ambitions presents challenges and opportunities for the ES community (Lim et al., 2017). Our team of 14 Early-Career Specialists (ECS) explores these risks and rewards, followed by recommendations for enhancing engagement and advancement of future ES leaders and experts.

Despite ES's wide adoption as a sustainability framework, the field still struggles to embrace diverse perspectives (Peterson et al., 2018); we argue that this shortcoming extends to engaging ECS. In this community where founding members are still actively involved, finding a niche as a newcomer, where one can elevate his/her voice and contribute to theory and practice, can be difficult. Additionally, while calls for greater interdisciplinarity and community-engaged research may be critical to the uptake of ES for decision-making (Bennett, 2017; Costanza et al., 2017), this route can be risky because of inadequate institutional (political and social) support, especially for those early in their careers (Dooling et al., 2017; Hein et al., 2018). These barriers, in conjunction with the common financial and mental stress associated with postsecondary education in science and academia (Belluz et al., 2016), may outweigh the benefits for future experts, limiting the influx of new talent and capacity (Rhoten and Parker, 2004).

The world must "mobilize all of its talents" to solve global sustainability challenges (Brück et al., 2010), and ECS have the potential to lead ES in new, exciting directions. Many ECS exhibit a strong interest in social justice and real-world problem solving, and seek to broaden the impact of ES on societal and ecological decisions, policies, and practices (Rhoten and Parker, 2004). Our exposure to diverse cultures, values, experiences, and epistemologies, alongside our familiarity with emerging communication and engagement technologies, provides us with the skills to bridge diverse disciplines, stakeholders, and sectors (Costanza et al., 2017; Lambini and Heubach, 2017). Moreover, ECS already produce high-quality, innovative science (Ebadi and Schiffauerova, 2016). One initiative already recognizing and building on this potential is the Young Ecosystem Services Specialists (YESS) network (Böhnke-Henrichs et al., 2014). Since 2011, YESS has expanded to over 420 members worldwide and has hosted engagement-driven sessions at multiple conferences, along with facilitating a multitude of ongoing capacity-building activities (e.g., Bull et al., 2016).

Given these benefits, we argue that further investment in ECS' professional development and inclusion will strengthen the field's continuity and longevity, as well as enhance the use of ES in global conservation and sustainable development efforts. To this end, we present several actions that we consider critical stepping stones for meaningfully engaging the next generation:

- Remove barriers for engagement: Several opportunities exist within the ES community to increase equitable participation of ECS. We encourage all ES events and conferences to offer reduced rates for attendees five years or fewer post-graduate degree. We also propose establishing a research fund for ECS that could serve as a platform for showcasing innovative ideas (e.g., NSF CAREER and ESIP FUNding Friday). ES journals can reduce fees and expand opportunities for ECS, such as across-career special issues or present-to-publish programs (The Editors, 2019). The ES community also should continue to promote interdisciplinary work by 
increasing coverage in related journals and by advocating for academic institutions to recognize and reward community and policy-level contributions (e.g., the San Francisco Declaration on Research Assessment, 2013). Further, some early career-specific funding could be prioritized towards interdisciplinary work.

- Create direct, long-term mentoring and networking programs: Professional societies like ACES and ESP play a key role in providing networking opportunities, which pave the way for future job and collaboration opportunities (Ansmann et al., 2014; Daily, 1999). We encourage growing mentor and network programs, particularly for community members in developing countries (Dike et al., 2018). Conference fellowships, like ACES program for graduate students, are extremely valuable, and we encourage expanding such opportunities further to cover multiple experiences (e.g., the IPBES Fellowship Programme) and more directly facilitate networking between early career attendees and established professionals, for example, through reverse mentoring (Morris, 2017).

- Extend leadership positions: We recommend that ES advisory and journal boards, sciencepolicy initiatives, and event committees create permanent positions for ECS. For conferences, we recommend recruiting ECS to serve on the planning committee and to help develop activities specifically geared toward early career attendees. Further, we advocate future conferences mandate all activities feature diverse representation, to include ECS and local ES experts or practitioners.

- Increase learning opportunities: Recognizing many educational and training opportunities already exist, the ES community should evaluate potential areas of need and draw from other fields to guide future development of interdisciplinary courses, programs, and standards (Gustafsson, 2018; Welch-Devine et al., 2014). For instance, developing introductory-level modules for all ages - elementary through university - could introduce a wider range of students to the science and practice of ES. We highly encourage the development and expansion of formal trainings offered by ES organizations and experts, as well as more informal resources like those listed by ESP. In particular, we envision creating an immersive workshop that regularly brings together ECS and established leaders to allow mutual learning through discussion of the field's key ideas, techniques, and needs.

Together, these actions lay out a progressive strategy for meaningfully engaging and developing ECS in ES. Being early in our careers, we want to ensure our chosen field thrives, and believe a high investment in emerging experts now will yield high returns for the future planet and human well-being. We hope these ideas will advance ongoing efforts to promote an inclusive ES community that welcomes and embraces diverse perspectives.

\section{Acknowledgements}

We would like to thank A Community on Ecosystem Services and the Young Ecosystem Services Specialists groups for bringing this group together at the 2018 ACES meeting.

\section{Research data for this article}

Data not available / No data was used for the research described in the article 


\section{References}

Ansmann, L., Flickinger, T.E., Barello, S., Kunneman, M., Mantwill, S., Quilligan, S., Zanini, C., Aelbrecht, K., 2014. Career development for early career academics: Benefits of networking and the role of professional societies. Patient Education and Counseling 97, 132-134. https://doi.org/10.1016/j.pec.2014.06.013

Belluz, J., Plumer, B., Resnick, B., 2016. The 7 biggest problems facing science, according to 270 scientists [WWW Document]. Vox. URL https://www.vox.com/2016/7/14/12016710/science-challegesresearch-funding-peer-review-process (accessed 3.14.19).

Bennett, E.M., 2017. Research Frontiers in Ecosystem Service Science. Ecosystems 20, 31-37. https://doi.org/10.1007/s10021-016-0049-0

Böhnke-Henrichs, A., Baulcomb, C., Alam, M., Rawlins, M., Koss, R., Jobstvogt, N., 2014. YESS - The network for Young Ecosystem Services Specialists. Ecosystem Services 9, 216-217. https://doi.org/10.1016/j.ecoser.2014.06.001

Brück, T., Beaudry, C., Hilgenkamp, H., Karoonuthaisiri, N., Mohamed, H.S.-E., Weiss, G.A., 2010. Empowering Young Scientists. Science 328, 17-17. https://doi.org/10.1126/science.1185745

Bull, J.W., Jobstvogt, N., Böhnke-Henrichs, A., Mascarenhas, A., Sitas, N., Baulcomb, C., Lambini, C.K., Rawlins, M., Baral, H., Zähringer, J., Carter-Silk, E., Balzan, M.V., Kenter, J.O., Häyhä, T., Petz, K., Koss, R., 2016. Strengths, Weaknesses, Opportunities and Threats: A SWOT analysis of the ecosystem services framework. Ecosystem Services 17, 99-111. https://doi.org/10.1016/j.ecoser.2015.11.012

Costanza, R., de Groot, R., Braat, L., Kubiszewski, I., Fioramonti, L., Sutton, P., Farber, S., Grasso, M., 2017. Twenty years of ecosystem services: How far have we come and how far do we still need to go? Ecosystem Services 28, 1-16. https://doi.org/10.1016/j.ecoser.2017.09.008

Daily, G., 1999. Developing a Scientific Basis for Managing Earth's Life Support Systems. Conservation Ecology 3. https://doi.org/10.5751/ES-00140-030214

Dawson, N., Coolsaet, B., Martin, A., 2018. Justice and equity: emerging research and policy approaches to address ecosystem service trade-offs, in: Schreckenberg, K., Mace, G., Poudyal, M. (Eds.), Ecosystem Services and Poverty Alleviation. Trade-Offs and Governance. Taylor \& Francis, pp. 22-38.

Dike, V.N., Addi, M., Andang'o, H.A., Attig, B.F., Barimalala, R., Diasso, U.J., Plessis, M.D., Lamine, S., Mongwe, P.N., Zaroug, M., Ochanda, V.K., 2018. Obstacles facing Africa's young climate scientists. Nature Clim Change 8, 447-449. https://doi.org/10.1038/s41558-018-0178-x

Dooling, S., Graybill, J.K., Shandas, V., 2017. Doctoral Student and Early Career Academic Perspectives on Interdisciplinarity. The Oxford Handbook of Interdisciplinarity. https://doi.org/10.1093/oxfordhb/9780198733522.013.46

Ebadi, A., Schiffauerova, A., 2016. How to boost scientific production? A statistical analysis of research funding and other influencing factors. Scientometrics 106, 1093-1116. https://doi.org/10.1007/s11192-015-1825-x

Gustafsson, K.M., 2018. Producing expertise: the Intergovernmental Science-Policy Platform on Biodiversity \& Ecosystem Services' socialisation of young scholars. Journal of Integrative Environmental Sciences 15, 21-39. https://doi.org/10.1080/1943815X.2018.1439509

Hein, C.J., Hoeve, J.E.T., Gopalakrishnan, S., Livneh, B., Adams, H.D., Marino, E.K., Weiler, C.S., 2018. Overcoming early career barriers to interdisciplinary climate change research. WIREs Climate Change 9, e530. https://doi.org/10.1002/wcc.530

Himes, A., Muraca, B., 2018. Relational values: the key to pluralistic valuation of ecosystem services. Current Opinion in Environmental Sustainability, Sustainability Challenges: Relational Values 35, 1-7. https://doi.org/10.1016/j.cosust.2018.09.005

Irvine, K.N., O’Brien, L., Ravenscroft, N., Cooper, N., Everard, M., Fazey, I., Reed, M.S., Kenter, J.O., 2016. Ecosystem services and the idea of shared values. Ecosystem Services, Shared, plural and cultural

values 21, 184-193. https://doi.org/10.1016/j.ecoser.2016.07.001

Lambini, C.K., Heubach, K., 2017. Public engagement: Young scientists welcome at IPBES. Nature 550, 457-457. https://doi.org/10.1038/550457a

Lim, M., Lynch, A.J., Fernández-Llamazares, Á., Balint, L., Basher, Z., Chan, I., Jaureguiberry, P., Mohamed, A., Mwampamba, T.H., Palomo, I., Pliscoff, P., Salimov, R.A., Samakov, A., Selomane, O., Shrestha, 
U.B., Sidorovich, A.A., 2017. Early-career experts essential for planetary sustainability. Current Opinion in Environmental Sustainability 29, 151-157. https://doi.org/10.1016/j.cosust.2018.02.004

Morris, L.V., 2017. Reverse Mentoring: Untapped Resource in the Academy? Innov High Educ 42, $285-287$. https://doi.org/10.1007/s10755-017-9405-Z

Peterson, G., Harmáčková, Z., Meacham, M., Queiroz, C., Jiménez-Aceituno, A., Kuiper, J., Malmborg, K., Sitas, N., Bennett, E., 2018. Welcoming different perspectives in IPBES: "Nature's contributions to people" and "Ecosystem services." Ecology and Society 23. https://doi.org/10.5751/ES-10134230139

Rhoten, D., Parker, A., 2004. Risks and Rewards of an Interdisciplinary Research Path. Science 306, $2046-$ 2046. https://doi.org/10.1126/science. 1103628

San Francisco Declaration on Research Assessment [WWW Document], 2013. URL https://sfdora.org/.

Schröter, M., Stumpf, K.H., Loos, J., van Oudenhoven, A.P.E., Böhnke-Henrichs, A., Abson, D.J., 2017. Refocusing ecosystem services towards sustainability. Ecosystem Services 25, 35-43. https://doi.org/10.1016/j.ecoser.2017.03.019

The Editors, 2019. The future of scholarly publishing: Paywalls and profits or a new plan? Geoforum 102, 14. https://doi.org/10.1016/j.geoforum.2019.03.005

van Riper, C.J., Landon, A.C., Kidd, S., Bitterman, P., Fitzgerald, L.A., Granek, E.F., Ibarra, S., Iwaniec, D., Raymond, C.M., Toledo, D., 2017. Incorporating Sociocultural Phenomena into Ecosystem-Service Valuation: The Importance of Critical Pluralism. BioScience 67, 233-244. https://doi.org/10.1093/biosci/biw170

Welch-Devine, M., Hardy, D., Brosius, J., Heynen, N., 2014. A pedagogical model for integrative training in conservation and sustainability. Ecology and Society 19. https://doi.org/10.5751/ES-06197-190210 